\title{
CLASSROOM PROCESS IN TEACHING PASSIVE VOICE TO THE MECHANICAL ENGINEERING STUDENTS AT STT HARAPAN MEDAN
}

\author{
Dharmawati \\ Department of Information Technology, \\ Higher School of Technology, Harapan Medan \\ dharmawati66@yahoo.com
}

\begin{abstract}
This paper deals with the classroom process in teaching English to Mechanical Engineering students of STT Harapan Medan. The objectives of this research are to show how Passive voice is taught to Students in Mechanical Engineering of STT Harapan. It was conducted by applying qualitative method. The data analysis showed that teaching structure especially passive voice needs both lecturer's competence and students' ability to make ESP teaching successful. The lecturer's reasons for selecting passive voice as the teaching material in conducting the classroom process were based on the belief that the material was suitable to be taught to the mechanical engineering students. It is suggested to the lecturer to always update, revise and suit the teaching materials to find out the best strategy and media to make teaching ESP successful.
\end{abstract}

\section{Abstrak}

Tulisan ini berhubungan dengan proses kelas selama mengajar bahasa Inggris kepada mahasiswa teknik mesin di STT Harapan Medan. Tujuan tulisan ini untuk menunjukkan bagaimana passive voice diajarkan pada mahasiswa teknik mesin di STT Harapan. Penelitian ini menggunakan metode kualitatif. Hasil penelitian ini menunjukkan bahwa mengajarkan struktur tata bahasa khususnya kalimat pasif membutuhkan kompetensi dosen dan mahasiswa untuk membuat pengajaran ESP berhasil. Alasan dosen dalam memilih bahan ajar bentuk kalimat pasif dalam proses kelas didasarkan pada keyakinan bahwa bentuk kalimat ini sesuai diajarkan untuk mahasiswa teknik mesin. Dosen disarankan untuk selalu memperbaharui bahan ajar dan merevisinya untuk mengetahui strategi terbaik dan media yang tepat untuk membuat pengajaran ESP untuk mahasiswa berhasil.

Keywords: classroom process, passive voice, teaching strategy. 


\section{INTRODUCTION}

English is learnt for various different purposes. Some learners of English learn Business English, Technical English, Medical English, etc. and this is known as ESP (English for Specific Purpose). In contrast the variable characteristics of ESP as defined by Dudley Evans may be designed for a very specific discipline; for instance, medicine or mechanical engineering may use quite a different methodology from that used for teaching general English (Christine, 2008: 54)

Teaching ESP is different from teaching other language skills. Teaching ESP is based on the principle of effectiveness and efficiency. It is also concerned with the designs of curriculum, approaches, methods and techniques in advanced ESP and the teacher should develop the materials for the syllabus. ESP is generally based on need analysis, which is aimed at specifying what exactly the students' need in studying English is.

Rustam (1999: 32) reports his investigation that most Indonesian teachers of English do not develop their syllabus and materials systematically based on the teacher's preferences and the learner's need. As a result the students are not motivated to learn because they learn something they do not need.

Grammar is one of the important material in English teaching as good sentences which are understandable must be based on the right grammar of English and ungrammatical sentences will make the hearer or the reader confused and unable to understand them. Passive voice is a material in English grammar which is taught from the junior high school level untill the university level.

Based on the researcher's observation, passive voice is taught to the students of mechanical engineering at STT Harapan Medan. The grammar of passive voice is taught to mechanical engineering students so that the students understand and able to use passive voise well in their written and spoken English and consequently, they can also comprehend English books as most mechanical engineering books are written in English.

Teaching in higher education level or university level is a complex process which can be affected by many factors. These include teacher and student 
characteristics, institutional culture, syllabus, materials and approaches to teaching and learning demonstrated by teachers and students (Dunkin \& Biddle, 1974: 23).

In this paper, the writer is interested in observing the process variable which is focused in the lecturer in presenting English materials especially passive voice to the mechanical engineering students, and such a process variable is called by classroom process. Dunkin and Biddle (1974) defined these process variables as the activities taking place in the classroom. This study is an attempt to find out how passive voice is taught in mechanical engineering students.

The paper will be limited to one of four teaching variables as proposed by Dunkin and Biddle (1974). The process variable refers what is happening or what is being done by the teacher and students. So the focus is both the teacher and students' behaviour during the real classroom activities. What is going on there in the classroom is the form of the students' and teachers' behaviour which can not be seperated from other related aspects, such as teaching materials which are derived from predetermined syllabus, predetermined lesson plan on which the teacher's behavoiur are based on the position of these related aspects supporting aids in the attempt to understand the teachers' and the students' behaviour during the teaching process as the process variable as mentioned by Dunkin and Biddle (1974). From the process variable or teachers' variable and students' variable, only the teacher's behaviour is considered as the focused.

The significance of this research theoritically and practically is of the following aspects.

1. Theoretically, the findings of this research are expected to support the theory of Dunkin and Biddle in developing teaching ESP particularly for mechanical engineering students.

2. Practically, this research findings can also help the ESP lecturers overcome their problem in teaching ESP. The research findings are also expected to be useful as an input for Specific Purpose Lectures. It is expected to provide information about the teaching of English at Mechanical Engineering students. 


\section{Theory of Teaching}

Teaching is a social process, to define it is very difficult because teaching is influenced by the political and social background of a country. Teaching can also be defined as the process of providing opportunities to the learner and occurs through telling, persuading, showing, demonstrating, illustrating, explaining, guiding and directing learners through a variety of selected learning materials and experiences. It is designed to impart knowledge, skills and attitudes to the learner.

Teaching is an art form of all its own. It has order, function, purpose, meaning, and, like art, evolves and takes shape within the imagination and mind of the teacher. Peter (2010) says teaching is a set of interrelated constructs, definitions, propositions which present a systematic view of teaching by specifying relations among variables with the purpose of explaining and predicting.

Classroom teaching learning processes have been guided by the following terms such as teaching models, teaching strategies, teaching style, etc. Different level and age of students need different models, strategies and style that are applied to teach them.

Model of teaching can be defined as instructional design which describes the process of specifying and producing particular environmental situations which cause the students to interact in such a way that a specific change occurs in their behavior.

Dunkin and Biddle (1974) have provided four models of classroom teaching and learning that are useful for understanding many factors that must be considered by classroom teachers-provided that the goal is student learning. The models are presage variables, context variables, process variables, and product variables. The variables start in the broad context of the classroom and filter into the classroom to produce the product variables.

\section{Presage Variables}

Presage variables are those variables associated with the teacher. These variables affect the behavior of the teacher in the classroom. Examples of these variables are personality traits, teaching skills, and teaching styles (1974: 39). Examples of presage 
Classroom Process in Teaching Passive Voice to the Mechanical Engineering Students at STT Harapan Medan, Dharmawati

variables in this study are the teacher's ability to use the technology and the willingness or attitudes surrounding the use of the audience respons system.

The teacher formative experiences such as social class, age, and gender may influence their teacher training experiences. These teacher training experiences are such as the university attended by the unique features of the teacher education program, and student's teaching experiences, combined with some characteristics which are called teacher properties-their teaching skills, overall intelligence, motivation, and personality traits, and all of them tend to influence the behavior of the teacher in the classroom.

\section{Context Variables}

Context variables are presented as those to which the teacher must adapt, or "characteristics of the environment about which teachers, school administrators, and teacher educators can do very little". These variables deal with the students' experiences that help them develop characteristics prior to entering the classroom (1974: 44).

Context variables in this model are those that are not totally in the control of the teacher. They are attributed to the students, the school, and the community. Nevertheless, they have an impact on student learning - at least indirectly. Student formative experiences combined with student properties (abilities, knowledge, attitudes) to influence student classroom behavior. Within the classroom, there are factors that contribute to student behavior. Some of these may be the class size, the availability of textbooks or other reference materials, and the authors suggested educational TV as a variable, and today's educational context would add availability of computers in the classroom.

\section{Process Variables}

Dunkin and Biddle (1974) defined process variables as the activities taking place in the classroom. These variables are outcomes and interactions of behaviors. Examples of process variables are student-student interactions, student-teacher interactions, teacher behaviors, and student behaviors (1974: 46). Examples of the 
process variable in this study is the method of feedback delivery, either technologybased or non-technology based.

The model shows the interaction between teacher behavior and student behavior resulting in observable changes in student behavior. This is the desired outcome-that student behavior will change in a positive manner. Teacher classroom behavior includes how the teacher conducts the classes, carries out the lesson plan, treats students, manages student behavior, evaluates student performance, and generally interacts with the students in the classroom. The student behavior includes not only the conduct of the student in the class, but also the way they approach learning, their willingness to participate in class, their performance on learning activities, and the way they treat other students in the classroom.

\section{Product Variables}

The fourth category of variables in this model is termed product variables. Product variables are all of the outcomes of the activities from within the classroom, both positive and negative. Although these are typically mentioned in a positive context, teacher and student interactions can hamper or harm the students in their learning process (1974: 46). They simply describe the desired outcomes of education. Certainly the teacher should be concerned with immediate pupil growth with respect to learning the subject matter taught and developing positive attitudes toward the subject. Other skills, especially social skills in working as teams and getting along with other students should be a desired immediate outcome, as well. However, teachers must also be concerned with long-term effects of education-the development of a person's adult personality, the development of professional competence, and the attitude that learning continues throughout the lifetime of the person. The long-term outcomes are the ultimate measure of the effectiveness of an educational experience. This Dunkin and Biddle's Model (1974) for the Study of Classroom Teaching is shown in the Figure below. 
Classroom Process in Teaching Passive Voice to the Mechanical Engineering Students at STT Harapan Medan, Dharmawati

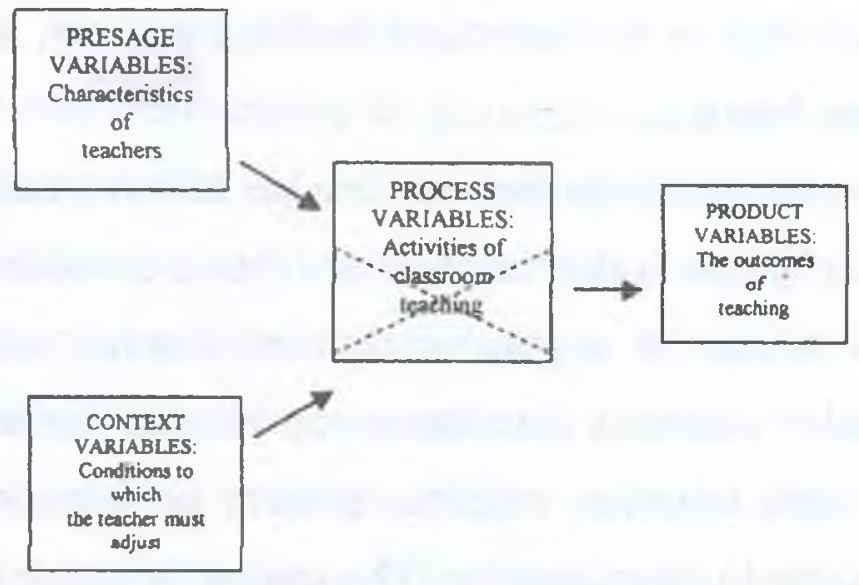

Figure 1: Dunkin and Biddle's Model (1974) for the Study of Classroom Teaching

\section{Classroom Process}

Classroom is considered as the most important place for foreign language learner to apply and practice target-language. Classroom can be defined as a room in which teaching or learning activity can take place. Classroom is the primary forum for foreign language learners to use and experience target language. In order to make foreign language learners learn the target language better, they should create communication between teacher and students in the classroom. Communication in the classroom can be built through communication. Process is a series of actions or steps taken in order to achieve a particular purpose.

\section{ESP (English for Specific Purposes)}

ESP derives from the need to use language as a tool in facilitating success in professional life. ESP is understood to be about preparing learners to use English within academic, professional, or workplace environments, and a key feature of ESP course design is that the syllabus is based on an analysis of the needs of the students.

English for Specific Purpose is a particular case of the general category of specific purpose language teaching. The same principles apply no matter which language is being learned and taught. Hutchinson et al. (1987:19) state, "ESP is an approach to language teaching in which all decisions as to content and method are based on the learner's reason for learning". 


\section{Material Design}

Designing a course is fundamentally a matter of asking question in order to provide a reasonable basis for the subsequent process of syllabus design, materials writing, classroom teaching and evaluation (1986: 96).

The ESP course designing process involves one last major question: WHAT exactly are the materials used during the course? After having completed the needs analysis, after having chosen the teaching theory, the teacher has to decide what materials he/she is going to use with his/her students. He/she has three possibilities of actually transforming his/her course design in teaching materials:

1. Materials evaluation is a process of selecting from already existing materials;

2. Materials development is a process of writing new materials;

3. Materials adaptation is a process of selecting and modifying existing materials.

Before planning the course, a wide range of questions (general and specific, theoretical and practical) needs to be asked. Some of them will be answered based on research findings, while other rely more on the intuition and experience of the teacher, such as: (1) Why does the student need to learn?, (2) Who is going to be involved in the process?, (3) Where is the learning to take place?, (4) What potential does the place provide?, (5) What limitation does it improve?, (6) When is the learning to take place?, (7) How much time is available?, (8) Who will be distributed?, (9) What does the student need to learn?, (10) What aspect of language will be needed, and how will they be described?, (11) What level of proficiency must be achieved?, (12) What topic areas will need to be covered?, (13) How will the learning be achieved?, (14) What learning theory will underline the course?, and (15) What kind of methodology will be employed?

All of those basic questions will be investigated more thoroughly, by considering them under three main headings: (1) language descriptions, (2) theories of learning, and (3) need analysis. They are clearly shown in the enclosed Figure as taken from Hutchinson (1986). 


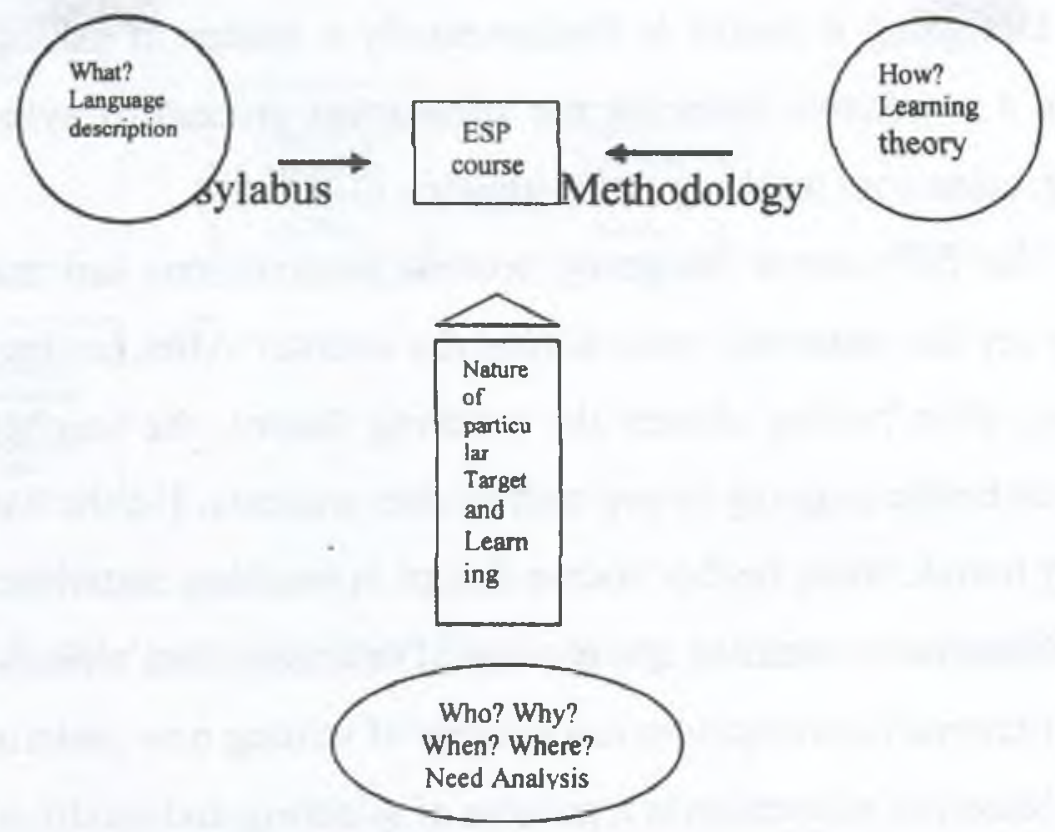

Figure 2: Target Situasion Analisis

\section{Passive Voice}

The passive voice is a grammatical construction (specifically, a "voice"). The noun or noun phrase that would be the object of an active sentence (such as Our troops defeated the enemy) appears as the subject of a sentence with passive voice (e.g. The enemy was defeated by our troops).

The subject of a sentence or clause featuring the passive voice denotes the recipient of the action (the patient) rather than the performer (the agent). The passive voice in English is formed periphrastically: the usual form uses the auxiliary verb be (or get) together with the past participle of the main verb.

\section{Mechanical Engineering}

Mechanical Engineering is an engineering discipline that was developed from the application of principles from physics and materials science. According to the American Heritage Dictionary, it is the branch of engineering that encompasses the generation and application of heat and mechanical power and the design, production, and use of machines and tools. It is one of the oldest and broadest engineering disciplines. 
Myer (2006: 24) states that basic engineering disciplines are not static, no matter how old and well established they are. The field of mechanical engineering is no exception. Movement within this broadly based discipline is multidimensional. Even the classic subjects on which the discipline was founded, such as mechanics of materials and heat transfer, continue to evolve. Mechanical engineers continue to be heavily involved with disciplines allied to mechanical engineering, such as industrial and manufacturing engineering, which are also constantly evolving. Advances in other major disciplines, such as electrical and electronics engineering, have significant impact on the work of mechanical engineers. New subject areas, such as neural networks, suddenly become all the rage.

Mechanical engineering plays a dominant role in enhancing safety, economic vitality, enjoyment and overall quality of life throughout the world. Mechanical engineers are concerned with the principles of force, energy and motion. The men and women who work as mechanical engineers are professionals with expert knowledge of the design and manufacture of mechanical systems and thermal devices and processes. Some examples of products and processes developed by mechanical engineers include engines and control systems for automobiles and aircraft, electric power generation plants, lifesaving medical devices and consumer products ranging from air conditioners to personal computers and athletic equipment. They also design the machines that mass-produce these products. Virtually every aspect of life is touched by mechanical engineering. If something moves or uses energy, a mechanical engineer was probably involved in its design or production.

\section{Research Design}

This paper will be conducted by applying descriptive qualitative design. How the teaching of English to Mechanical Engineering is conducted will be described in narration and description of the reasons underlying the performance was explained. Therefore, the qualitative research design employed is called by objective explanation description. 
The subject was the lecturer who taught English to the Mechanical Engineering students of Sekolah Tinggi Teknik (STT) Harapan Medan as the writer was one of the lecturers at this education institution.

\section{Data Collection}

The data used is collected by observation during teaching learning passive voice.

\section{Technique of Data Analysis}

The analysis of the data was done at the same time as the process of collecting the data by applying the interactive model of analysis. It was the interactive model of Miles and Huberman (1884: 23). The analysis consists of three current flows of activities; data collection, data display, and conclusion drawing.

\section{DISCUSSION}

\section{Classroom Process in the Teaching of English}

The classroom process refers to lecturers' and students' behaviour performed in every session of teaching English as well as to the teaching materials and media used during the behavioral performance and both teachers' and students' behaviour refers to both verbal and non-verbal behaviour. Based on the result of the data analysis it was found out that during the classroom process observed, there are three aspects involved in the classroom process, they are (1) Teaching Materials, (2) Competence Elaboration and (3) Classroom Process.

\section{Classroom Process in Teaching Passive Voice}

From the observation, it was found that one of the materials taught to the students during teaching English to mechanical engineering students was passive voice. Passive voice was taught to the second semester of mechanical engineering students, because it is one of important materials to master in order that the students can apply it in their daily activities. For example, when they want to cut the wire, they should say 'The wire can be cut', and it is expressed in the passive voice. In the 
teaching process of passive voice, the lecturer taught passive voice by firstly giving the definition of passive voice as shown in data 1 .

\section{Data 1}

L: This is the first time we meet in this semester. I hope in this semester you will be better than the first semester. Oke, today we are going to study Passive Voice. Do you, still remember what passive voice is? (The lecturer writes passive voice on the white board)

You, what is passive voice? (Pointing at one student)

S2: Passive Sentence, Madam.

L: Yes, passive sentence was your lesson when you were in the senior high school. Even in the junior high school you also studied passive sentence.

S3: Yes, Madam but we have forgotten how to make it.!

L: Passive sentence in English is a sentence in which the subject functions as the patient and the verb is in the past participle form and preceded by the verb to be which functions as the tense carrier.

S: Yes, Mam.

After giving the definition of Passive Voice, the lecturer gives the students the formula of changing active sentence into passive as shown in data 2.

\section{Data 2}

L: "Now... how can you change active sentence into passive? This is why you should study passive voice. In changing active sentence into passive, of course there is a rule that you have to follow. And you have to be careful and you must memorize the change of the verb because the past participle form of the verb (V3) is used in the passive."

The rule is: $S+T O B E+V 3+B Y+O$. 
After introducing the formula for changing the active sentence into passive, the lecturer should give some examples by applying the formula to a simple sentence. The students should identify the tense in the active sentence as shown in data 3.

\section{Data 3}

L: "Ok... we continue now. If you want to change an active sentence into the passive voice, you must identify the tense used and you will find it easy to determine the formula which is used."

"Based on the tenses used in the active sentences, the formulas of changing active into passive in English are classified into the following:

\section{Simple Present Tense:}

Object + is/am/are + past participle + by subject
a. Our lecturer gives us a new lesson.
b. A new lesson is given to us by our lecturer.
c. Our lecturer gives us new lessons.
d. New lessons are given to us by our lecturer.

\section{Simple Past Tense:}

Object + was/were + past participle + by subject
a. Our lecturer gave us a new lesson.
b. A new lesson was given to us by our lecturer.
c. Our lecturer gave us new lessons.
d. New lessons were given to us by our lecturer.

\section{Present Continuous Tense:}

Object + is/am/are + being + past participle + by subject
a. Our lecturer is giving us a new lesson.
b. A new lesson is being given to us by our lecturer.
c. Our lecturer is giving us new lessons.
d. New lessons are being given to us by our lecturer. 


\section{Past Continuous Tense:}

Object + was/were + being + past participle + by subject

a. Our lecturer was giving us a new lesson.

b. A new lesson was being given to us by our lecturer.

c. Our lecturer was giving us new lessons.

d. New lessons were being given to us by our lecturer.

\section{Present Perfect Tense:}

Object + have/has + been + past participle + by subject

a. Our lecturer has given us a new lesson.

b. A new lesson has been given to us by our lecturer.

c. Our lecturer has given us new lessons.

d. New lessons have been given to us by our lecturer.

\section{Past Perfect Tense:}
Object + had + been + past participle + by subject
a. Our lecturer had given us a new lesson.
b. A new lesson had been given to us by our lecturer.
c. Our lecturer had given us new lessons.
d. New lessons had been given to us by our lecturer.

\section{Present/Past Future Tense (or any sentence with modal auxiliary):}

Object + modal + be + past participle + by subject

a. Our lecturer will give us a new lesson.

b. A new lesson will be given to us by our lecturer.

c. Our lecturer can give us new lessons.

d. New lessons can be given to us by our lecturer.

\section{Present/Past Future Perfect Tense (or other related sentence):} Object + modal + have + been + past participle + by subject

a. Our lecturer would give us a new lesson.

b. A new lesson would be given to us by our lecturer. 
Classroom Process in Teaching Passive Voice to the Mechanical Engineering Students at STT Harapan Medan, Dharmawati

c. Our lecturer might give us new lessons.

d. New lessons might be given to us by our lecturer.

Observe that the auxiliary used in each of the passive forms given above are different respectively depending on the tense used.

After explaining the tense and the formula used in each tense and some examples, the lecturer should ask the students to do some exercises, as shown in data 4.

\section{Data 4}

L: "Now, after you know the formulas for changing active sentences into passive sentences, I will give you some some exercises by changing the following active sentences into their corresponding passive."

1. My sister writes a letter.

2. We are studying English.

3. The Director closed the meeting.

4. My brother would play football next week.

5. The bride has invited many friends.

6. He can solve such problems.

7. Next week uncle Tom will have sold his car.

8. The students have bought the dictionary.

9. At nine a.m. the lecturer will be teaching us Japanese.

10. All the members support the Director's decree,

\section{Data 5}

After all the students had finished doing the exercises, the lecturer corrected the students' work and gave back the corrected paper to the students so that they could see their mistakes and they could correct their own mistakes. The teaching of passive to the students of STT Harapan Medan was a great success as all the students could do the exercises successfully. 
Thus, the steps of teaching passive voice in the classroom process are:

1. Explaining the definition of Passive Voice

2. Identifying the tense on the active sentence

3. Giving the formula for changing active into passive voice

4. Exemplifying some sentences

5. Asking the students to do some exercises

Visually the classroom process in teaching passive voice can be shown in Figure 3:

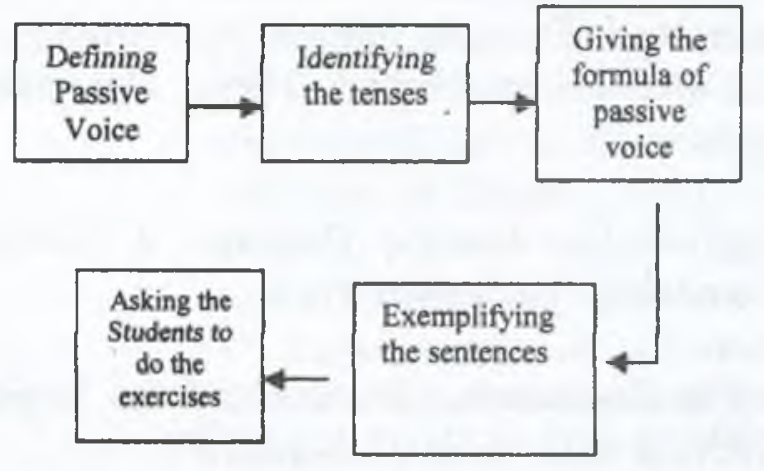

Figure 3: The Classroom Process in Teaching Passive Voice

\section{CONCLUSION}

Based on the research result, it is concluded that in teaching passive voice, the lecturer should first explain the definition of passive voice to the students, identify the tenses which involve in the sentences, provide the formula to change active sentence into the corresponding passive, give some examples in the process of the change, and ask the students to do some exercises so that they can be familiar to express themselves in English both in the active and passive voice.

Further, it is suggested to English lecturer especially the ESP lecturer not only to spend the teaching-learning time by explaining the material but also to organize some activities for the students to make the classroom process more effective. For example, the lecturer asks the students to make a group and give one topic to discuss by using passive sentences. After having discussion, each group presents their discussion resul in front of the class. The other students can ask questions to the presenter. This activity can make the classroom process more effective. 


\section{REFERENCE}

Basturkmen, H. 2006. The Ideas and options in English for Specific Purpose. London: The University of Auckland.

Dudley-Evans, T., 2001. English for specific purposes. In: Carter, R., Nunan, D. (Eds.), Teaching English to Speakers of Other Language. Cambridge University Press, Cambridge, PP. 131-136.

Dunkin, M. J \& Biddle, B. 1974. The study of teaching. New York: Holt, Rinehart \& Winston, Inc.

Fauziah, A. 2008. Presage, Context, Process And Product: Influencing Variables In Literature Instruction In An ESL Context. Unpublished Thesis. Universitas Kebangsaan Kuala Lumpur. Malaysia.

Hutchinson, T, \& Waters, A. 1987. English For Specific Purpose: A learning Centered Approach. Cambridge: Cambridge University Press.

Indira, C. \& Meenakshisundaram. 2010. The Engineering Student and the English Language: A Fresh Remediation. IRWLE VOL. 6 No. II July20101.

Jordan, R. R. 2002. The Growth of EAP in Britain Journal of English for Academic Purposes, 1, 69- 78.

Liang, Ling-Ling. 2007. An ESP course for leisure management students of technological colleges. The Proceedings of the 16th International Symposium on English Teaching (pp. 467-473). Taipei: Crane Publishing.

Mayer, Kutz. 2006. Mechanical Engineers' Handbook Third Edition: Manufacturing and Management. John Wiley \& Sons, Inc., Hoboken, New Jersey.

Ozturk, I. (2007). The textual organization or research article Introductions in applied linguistics: Variability within a single discipline. English for Specific Purposes, 26, 1, 25-38. 